\title{
Knockdown of NLRP3 alleviates high glucose or TGFB1-induced EMT in human renal tubular cells
}

\author{
Shan Song', Duojun Qiu1, Fengwei Luo2, Jinying Wei1,3, Ming Wu1, Haijiang Wu1,3, Chunyang Du1,3, Yunxia Du1,3, \\ Yunzhuo Ren ${ }^{1,3}$, Nan Chen', Huijun Duan ${ }^{1,3}$ and Yonghong Shi1,3
}

1Department of Pathology, Hebei Medical University, Shijiazhuang, China

2Renal Division, Department of Medicine, The Second Hospital of Hebei Medical University, Shijiazhuang, China

${ }^{3}$ Hebei Key Laboratory of Kidney Diseases, Shijiazhuang, China

Correspondence should be addressed to H Duan or Y Shi: duanhj999@163.com or yonghongshi@126.com

\begin{abstract}
Tubular injury is one of the crucial determinants of progressive renal failure in diabetic nephropathy (DN), while epithelial-to-mesenchymal transition (EMT) of tubular cells contributes to the accumulation of matrix protein in the diabetic kidney. Activation of the nucleotide binding and oligomerization domain-like receptor family pyrin domaincontaining 3 (NLRP3) inflammasome leads to the maturation of interleukin (IL)-1B and is involved in the pathogenic mechanisms of diabetes. In this study, we explored the role of NLRP3 inflammasome on high glucose (HG) or transforming growth factor-B1 (TGFB1)induced EMT in HK-2 cells. We evaluated EMT through the expression of $\alpha$-smooth muscle actin ( $\alpha-S M A)$ and E-cadherin as well as the induction of a myofibroblastic phenotype. Reactive oxygen species (ROS) was observed using the confocal microscopy. HG was shown to induce EMT at $48 \mathrm{~h}$, which was blocked by NLRP3 silencing or antioxidant N-acetyl-L-cysteine (NAC). We found that NLRP3 interference could inhibit HG-induced ROS. Knockdown of NLRP3 could prevent HG-induced EMT by inhibiting the phosphorylation of SMAD3, P38 MAPK and ERK1/2. In addition, P38 MAPK and ERK1/2 might be involved in HG-induced NLRP3 inflammasome activation. Besides, TGFB1 induced the activation of NLRP3 inflammasome and the generation of ROS, which were blocked by NLRP3 interference or NAC. Tubular cells exposed to TGFB1 also underwent EMT, and this could be inhibited by NLRP3 shRNA or NAC. These results indicated that knockdown of NLRP3 antagonized HG-induced EMT by inhibiting ROS production, phosphorylation of SMAD3, P38MAPK and ERK1/2, highlighting NLRP3 as a potential therapy target for diabetic nephropathy.
\end{abstract}

\section{Key Words}

- diabetic nephropathy

- NLRP3

- ROS

- EMT

- TGFB1
Journal of Molecular Endocrinology (2018) 61, 101-113

\section{Introduction}

Diabetic nephropathy (DN) is a worldwide predominant cause of chronic kidney disease (CKD) and the end-stage kidney failure (ESRD) (Fan et al. 2015). It is featured by an accumulation of extracellular matrix (ECM), a thickening of the glomerular basement membrane (GBM) and an increased mesangial matrix, ended up with the glomerulosclerosis and tubulointerstitial fibrosis (Loeffler et al. 2012). Tubulointerstitial fibrosis is the crucial pathological alteration underlying the progressive CKD in diabetes, while the transdifferentiation of renal tubular epithelial cells into myofibroblasts, namely, epithelial to mesenchymal transition (EMT), is momentous in 
tubulointerstitial fibrosis (Wei et al. 2013). Characterized by loss of epithelial phenotype and gain of profibrotic features, which is the feature of mesenchymal cells, EMT has been implicated in the accelerated fibrogenesis of renal tubular cells that is relevant with diabetic nephropathy (Morcos et al. 2002, Burns et al. 2006).

It has been reported that high glucose (HG) may be associated with lots of structural or functional alterations of renal tubular cells (Sun et al. 2008, Sun et al. 2011), and that EMT is one of the potential mechanisms of HG-induced nephrotic dysfunctions (Simonson 2007). Accumulating evidence implicates that HG-induced EMT contributes to the generation of renal fibrosis in diabetic nephropathy (Forbes et al. 2008). Further, renal tubular EMT can also be induced by transforming growth factor B1 (TGFB1) (Rhyu et al. 2005, Wei et al. 2013), and TGFB1 might be the key inducer of EMT since TGFB1 signaling is sufficient to induce EMT in cultured epithelial cells (Piek et al. 1999, Bottinger \& Bitzer 2002). Wang et al. (2017) demonstrated that IL17 could induce A549 alveolar epithelial cells to undergo EMT through the TGFB1mediated extracellular regulated protein kinases $1 / 2$ (ERK1/2) and Drosophila mothers against decapentaplegic protein2/3 (SMAD2/3) activation. Another study suggested that P38 mitogen-activated protein kinases (P38 MAPK) might play an important role in the HG-induced EMT in tubular epithelial cells (Lv et al. 2011).

Reactive oxygen species (ROS) are considered as critical signaling molecules modulating renal lesions in diabetes (Nishikawa et al. 2000). Besides, the generation of ROS by damaged or dysfunctional mitochondria, particularly $\mathrm{O}^{2-}$, has been well recognized as the principal initial event in the development of diabetic complications (Ha et al. 2002). High glucose, advanced glycation end products (AGEs), angiotensin II (Ang II), along with TGFB1, all could increase the intracellular ROS in renal cells and contribute to the progression of diabetic renal injuries (Jaimes et al. 1998, Yamagishi et al. 2003, Rhyu et al. 2005, Lee \& Han 2010). In addition, previous studies have shown that ROS-mediated HG, Ang II and TGFB1induced EMT in renal tubular cells (Stutz et al. 2009, Lee \& Han 2010, Chen et al. 2012). Thus, cutting down the production of ROS might have therapeutic effect on renal injuries related with diabetes.

Nucleotide binding and oligomerization domainlike receptor family pyrin domain-containing 3 (NLRP3) inflammasome, including the adaptor molecule apoptosisassociated speck-like protein containing a CARD (ASC) and pro-Caspase-1 (Nakahira et al. 2011, Shaw et al. 2011), is the best-featured inflammasome up to now and serves as a molecular platform for the maturation and secretion of interleukin-1B (IL1B) and interleukin-18 (IL18) (Shaw et al. 2011). Previous studies have verified that NLRP3 inflammasome was activated by a few sorts of stimuli in various cell types (Kim et al. 2015, Ding et al. 2016), especially in renal tubular epithelial cells (Vilaysane et al. 2010, Wang et al. 2015), and in the kidneys of diabetic animals (Fioretto \& Mauer 2007, Wang et al. 2015). One hypothesis suggests that NLRP3 activators have in common that they induce ROS, which, in turn, are sensed indirectly by NLRP3 leading to its activation (Dostert et al. 2008, 2009). HG and TGFB1 could induce ROS (Rhyu et al. 2005, Lee \& Han 2010), and the produced ROS, could lead to the generation of a potential ligand of NLRP3 or, alternatively, modify NLRP3 or associated proteins directly the other way round. However, the role of NLRP3 inflammasome on HG- or TGFB1-induced EMT via ROS in renal tubular epithelial cells is still unclear.

In the present study, we examined the activation of NLRP3 inflammasome in HG-treated HK-2 cells and the effects of knockdown of NLRP3 with shRNA on HG or TGFB1-induced EMT in vitro.

\section{Materials and methods}

\section{Reagents}

DMEM-F12 medium was purchased from Corning (Steuben County, NY, USA). D-glucose, mannitol, N-acetylcysteine (NAC), SB203580 and PD98059 were obtained from Sigma. FuGENE HD Transfection Reagent and the reverse transcription system were purchased from Promega and SYBR Premix Ex TaqTMII was from TaKaRa. Recombinant human TGFB1 was obtained from Abgent (San Diego, CA, USA). Antibody against NLRP3, IL18 and p-SMAD3 was purchased from Abcam. Antibodies for TGFB1, $\alpha$-smooth muscle actin ( $\alpha$-SMA), E-cadherin, Caspase- 1 and ASC were obtained from Proteintech (Chicago, IL, USA). Antibodies for P38 MAPK, ERK1/2, SMAD3, pP38 MAPK and pERK1/2 were purchased from Cell Signaling Technology. NLRP3 shRNA plasmid and control shRNA plasmid were obtained from Yingrun Biotechnologies, Inc (Changsha, China).

\section{Cell culture and transfection}

The HK-2 cells (ATCC) were cultured in a 95\% air, 5\% $\mathrm{CO}_{2}$ atmosphere at $37^{\circ} \mathrm{C}$ in DMEM-F12 (3:1) medium supplemented with $10 \%$ fetal bovine serum, $100 \mathrm{U} / \mathrm{mL}$ penicillin, and $100 \mu \mathrm{g} / \mathrm{mL}$ streptomycin. Stable transfections of HK-2 cells with NLRP3 shRNA plasmid 
or control shRNA plasmid were conducted with FuGENE HD Transfection Reagent (Promega) according to the manufacturer's instructions. The cells were cultured in serum-free DMEM-F12 medium for $6 \mathrm{~h}$, and then the substrate was changed into the original medium. After this period, HK-2 cells were stimulated with normal glucose (NG) $(5.6 \mathrm{mM}), \mathrm{HG}(30 \mathrm{mM})$, NG plus mannitol $(24.4 \mathrm{mM})$ as an osmotic control, HG plus NAC $(5 \mathrm{mM})$, HG plus TGFB1 $(4 \mathrm{ng} / \mathrm{mL})$, HG plus SB203580 $(10 \mu \mathrm{M})$ or HG plus PD98059 $(50 \mu \mathrm{M})$ at indicated time points.

\section{Quantitative RT-PCR analysis}

Total RNA and cDNA from HK-2 cells were prepared using TRIzol reagent and RT-PCR kits according to the manufacturer's instructions. cDNA was amplified using PCR with specific primers for NLRP3, ASC, Caspase-1, IL1B, IL18, E-cadherin, $\alpha$-SMA and 18s rRNA (Table 1). Real-time PCR was performed in a 96-well optical reaction plate using SYBR Premix Ex TaqTMII. Real-time PCR reactions were performed on Agilent Mx3000P QPCR Systems.

\section{Western blot analysis}

Proteins were extracted from HK-2 cells using RIPA buffer, separated by SDS-PAGE and then transferred to a PVDF membrane (Millipore). The membrane was incubated with the primary antibodies (NLRP3, ASC, Caspase-1, IL1B, IL18, P38 MAPK, pP38 MAPK, pERK1/2, ERK1/2, pSMAD3, SMAD3, $\alpha$-SMA, E-cadherin and $\beta$-actin) overnight at $4^{\circ} \mathrm{C}$ and incubated with goat anti-rabbit or

Table 1 The sequences of the PCR primer pairs used in this study.

\begin{tabular}{|c|c|c|}
\hline Gene & Sequences & $\begin{array}{l}\text { Product } \\
\text { size }(b p)\end{array}$ \\
\hline$N L R P 3$ & $\begin{array}{l}\text { sense } \text { 5'-TGAACAGCCACCTCACTT-3' }^{\prime} \\
\text { antisense 5'-CAACCACAATCTCCGAAT-3' }\end{array}$ & 170 \\
\hline ASC & $\begin{array}{l}\text { sense 5'-TGGACGCCTTGGACCTCA-3' } \\
\text { antisense 5'-GGACCTTCCCGTACAGAGCAT-3' }\end{array}$ & 225 \\
\hline Caspase-1 & $\begin{array}{l}\text { sense 5'-ATTACAGACAAGGGTGCT-3' } \\
\text { antisense 5'-GAATAACGGAGTCAATCAAA-3' }\end{array}$ & 101 \\
\hline$I L 1 B$ & $\begin{array}{l}\text { sense 5'-GTGGTGGTCGGAGATTCGTAG-3' } \\
\text { antisense 5'-GAAATGATGGCTTATTACAGTGGC-3' }\end{array}$ & 141 \\
\hline IL18 & $\begin{array}{l}\text { sense 5'-CTCACCACAACСТCTACCTCC-3' } \\
\text { antisense 5'-TTCAAGACCAGCCTGACCAAC-3' }\end{array}$ & 153 \\
\hline E-cadherin & $\begin{array}{l}\text { sense 5'-GAACGCATTGCCACATAC-3' } \\
\text { antisense 5'-ACCTTCCATGACAGACCC-3' }\end{array}$ & 156 \\
\hline$\alpha-S M A$ & $\begin{array}{l}\text { sense 5'-ATAACATCAAGCCCAAATC-3' } \\
\text { antisense 5'-ACTTCCCAAAGCATCAGC-3' }\end{array}$ & 245 \\
\hline $18 s$ & $\begin{array}{l}\text { sense 5'-ACACGGACAGGATTGACAGA-3' } \\
\text { antisense 5'-GGACATCTAAGGGCATCACAG-3' }\end{array}$ & 238 \\
\hline
\end{tabular}

mouse IgG horseradish peroxidase conjugate, and then scanned using the Odyssey Fc System (LI-COR, USA).

\section{Mitochondrial ROS detection}

The mitochondrial formation of ROS was detected using MitoSox (Sigma). After culture in six-well plates under the different experimental conditions for $48 \mathrm{~h}$, the cells were incubated with MitoSOX at a final concentration of $5 \mu \mathrm{M}$ for $30 \mathrm{~min}$ at $37^{\circ} \mathrm{C}$. Cells were washed twice with PBS and images were acquired using a confocal microscope (Leica, Germany). The mitochondrial ROS intensity was quantified using the software Image-Pro Plus 6.0.

\section{Immunofluorescence}

HK-2 cells were grown and stimulated in six-well chamber slides fixed with frozen acetone for $10 \mathrm{~min}$ at $4^{\circ} \mathrm{C}$. We punched the HK-2 cell membrane using Triton X-100. Then, the cells were incubated with anti- $\alpha$-SMA as well as E-cadherin antibody at $4^{\circ} \mathrm{C}$ overnight. Afterward, the HK-2 cells were exposed to goat anti-rabbit Alexa Fluor 594 conjugated secondary antibody for $1 \mathrm{~h}$ at $37^{\circ} \mathrm{C}$. Finally, the cells were examined by a fluorescence microscope (Olympus BX63).

\section{Statistical analysis}

The results from at least three independent experiments were expressed as mean \pm s.D.. Statistical analysis was performed by one-way ANOVA. Statistical significance was defined as $P<0.05$.

\section{Results}

\section{HG induces the activation of NLRP3 inflammasome in HK-2 cells}

To ascertain the role of HG in the activation of NLRP3 inflammasome in vitro, HK-2 cells were incubated with high concentration of glucose for varying time phases, and then, the protein and mRNA levels of NLRP3 inflammasome, IL1B and IL18 were determined. As shown in Fig. 1A, B and C, the expression of NLRP3, ASC and Caspase- 1 significantly increased in time-dependent manner in HK-2 cells treated with HG, which appeared to reach its maximum at the time point of $48 \mathrm{~h}$. We also measured the expression of IL1B and IL- 8 of HK-2 cells 
A

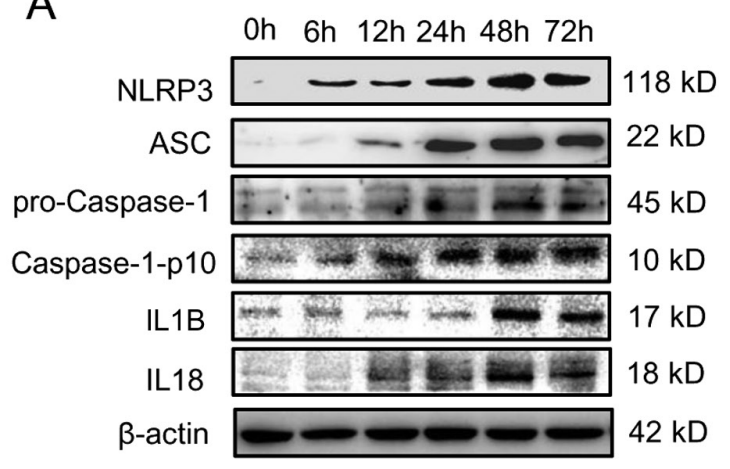

B

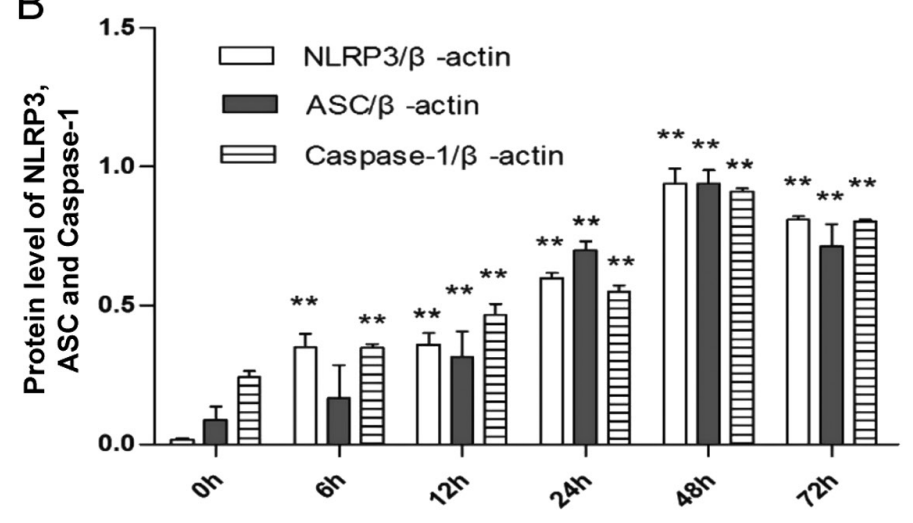

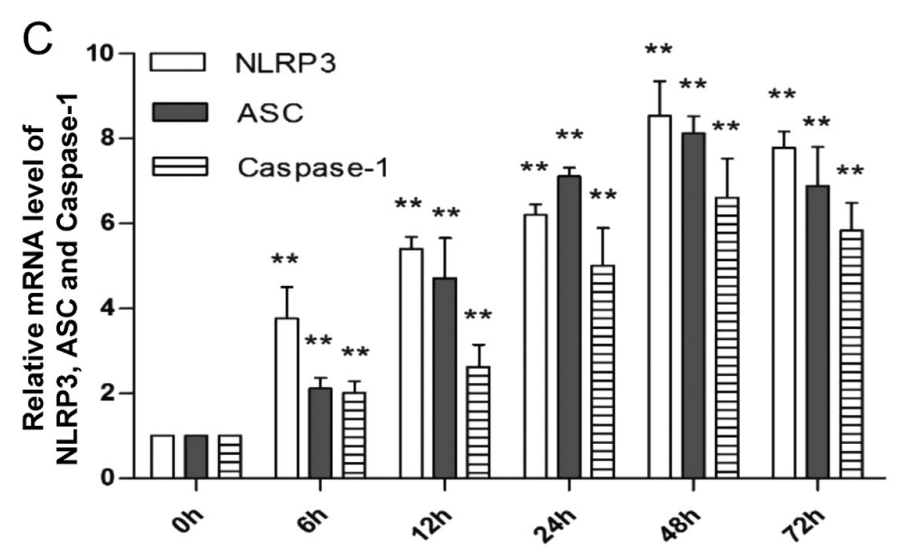
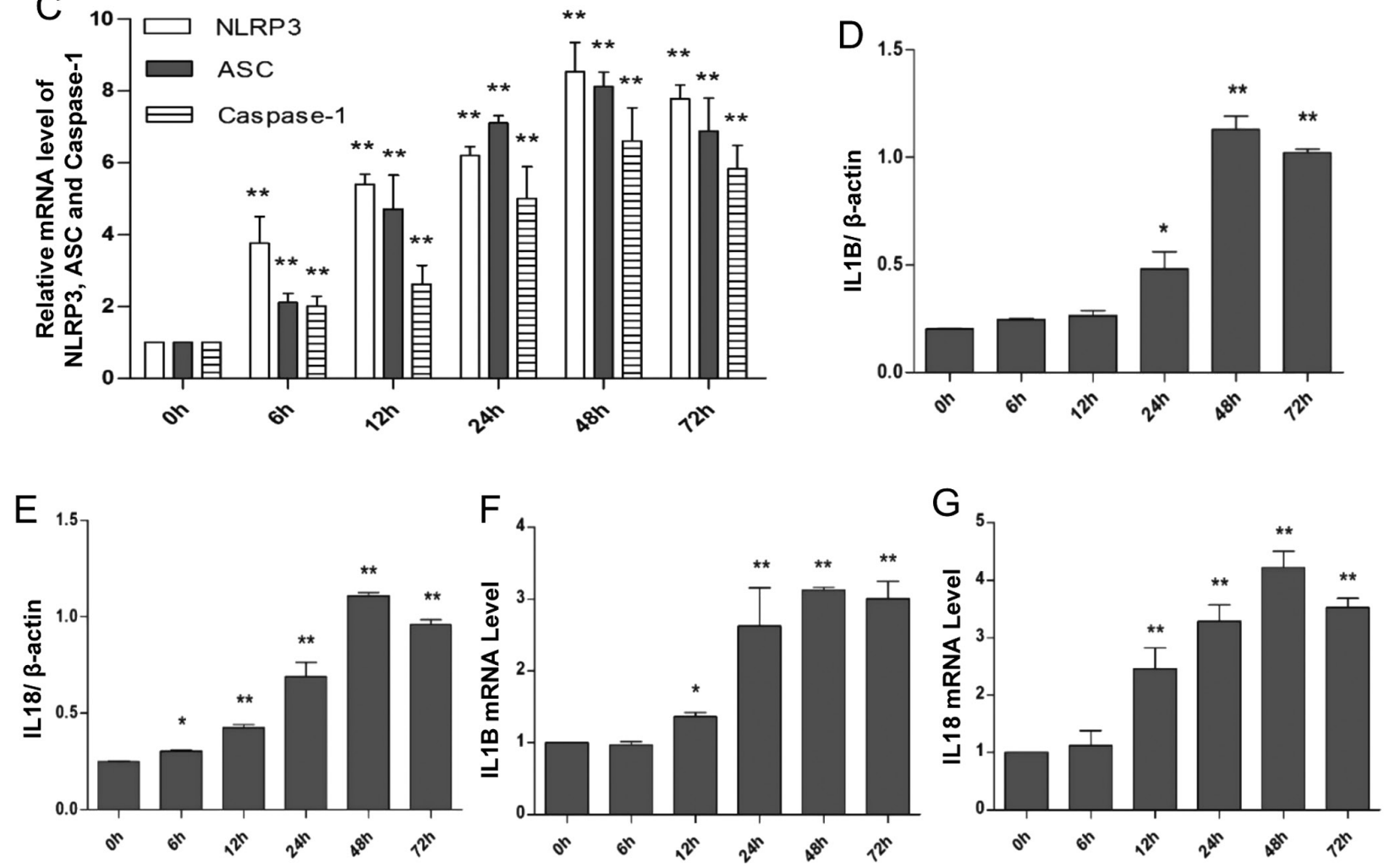

Figure 1

Activation of NLRP3 inflammasome in HG-treated HK-2 cells. (A) The activation of NLRP3 inflammasome in cultured HK-2 cells treated with HG (30 mM) at various time points were analyzed by Western blot $(n=6)$. (B) The quantitative analysis of NLRP3 inflammasome protein level in cultured HK-2 cells treated with HG $(30 \mathrm{mM})$ at various time points $(n=6)$. (C) The mRNA expression of NLRP3 inflammasome was analyzed by RT-qPCR $(n=6)$. (D and E) The quantitative analysis of protein level of IL1B and IL18 in HG-treated HK-2 cells at various time points $(n=6)$. (F and G) The mRNA expression of IL1B and IL18 was analyzed by RT-qPCR $(n=6)$. Values are expressed as mean \pm S.D. ${ }^{*} P<0.05, * * P<0.01$ vs control $(0 \mathrm{~h})$.

exposed to HG at six time points (0-72h) by Western blotting and RT-qPCR. The protein and mRNA levels of IL1B and IL18 were elevated within $6 \mathrm{~h}$ and kept on increasing until $72 \mathrm{~h}$, which reached its peak at $48 \mathrm{~h}$ (Fig. 1A, D, E, F and G). Besides, compared with those of the NG group, mannitol did not change the expression of any of these markers in HK-2 cells among different time points (data not shown).

\begin{tabular}{|lr}
\hline $\begin{array}{l}\text { http://jme.endocrinology-journals.org } \\
\text { https://doi.org/10.1530/JME-18-0069 }\end{array}$ & $\begin{array}{c}2018 \text { Society for Endocrinology } \\
\text { Published by Bioscientifica Ltd. } \\
\text { Printed in Great Britain }\end{array}$
\end{tabular}

\section{Knockdown of NLRP3 prevents HG-induced ROS generation}

In order to explore the effect of NLRP3 silencing on HG-induced activation of NLRP3 inflammasome, NLRP3 shRNA plasmid or control shRNA plasmid were transfected in HK-2 cells, followed by an incubation with $\mathrm{HG}$ for $48 \mathrm{~h}$. The protein levels of NLRP3, ASC, Caspase-1, IL1B 
and IL18 were significantly inhibited by transfection with NLRP3 shRNA plasmid under HG conditions (Fig. 2A, B, $\mathrm{D}$ and $\mathrm{E})$. RT-qPCR results were consistent with the results of Western blot (Fig. 2C, F and G). We also found that NAC, a sort of antioxidant, could prevent the activation of NLRP3 inflammasome and the expression of IL1B and IL18 efficiently (Fig. 2A, B, C, D, E, F and G). Then, ROS generation was detected using a fluorescence probe. The enhanced mitochondrial ROS levels induced by HG were obviously suppressed by transfection of NLRP3 shRNA plasmid or NAC treatment in HK-2 cells (Fig. 2H and I).

\section{Knockdown of NLRP3 prevents HG-induced EMT}

It has been reported that EMT is one of the potential mechanisms of HG-induced renal dysfunction (Wei et al.
2013). We investigated whether the activation of NLRP3 inflammasome could regulate HG-induced EMT in vitro. HK-2 cells that were cultured in NG or NG+mannitol presented a typical epithelial cuboidal shape with a featured cobblestone morphology; but the cells appeared to be more elongated, less adhered and lost their apicalto-basal polarity after incubated with HG or HG+control shRNA plasmid; while these morphological changes above induced by HG were reversed by NLRP3 silencing or NAC (Fig. 3F). Compared with the NG group, HG obviously elevated the expression of $\alpha$-SMA protein and descended the expression of E-cadherin protein (Fig. 3A, $\mathrm{B}$ and $\mathrm{C}$ ). However, these alterations induced by HG were significantly reversed by transfection with NLRP3 shRNA plasmid or NAC (Fig. 3A, B and C). The relative mRNA levels of E-cadherin and $\alpha$-SMA presented a similar trend
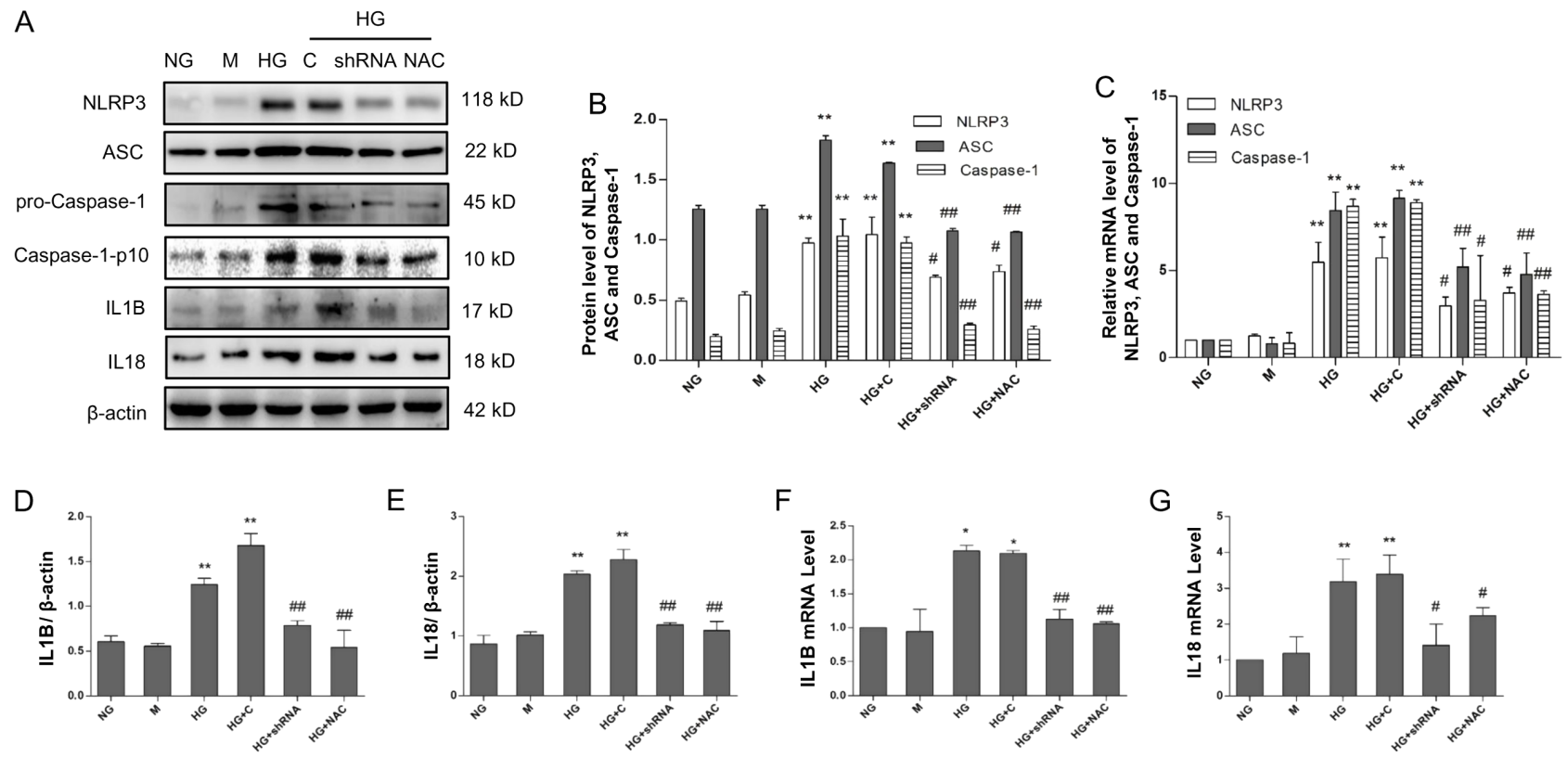

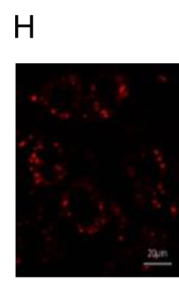

NG

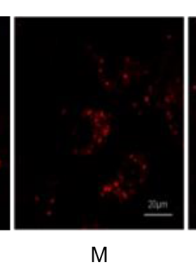

M

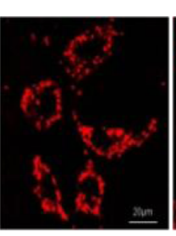

HG

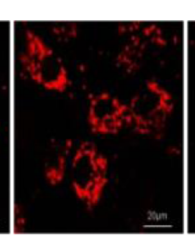

$\mathrm{HG}+\mathrm{C}$

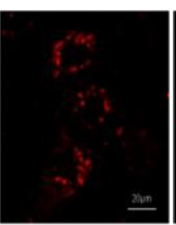

HG+shRNA

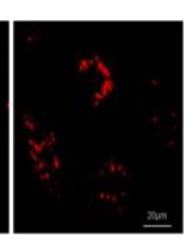

$H G+N A C$

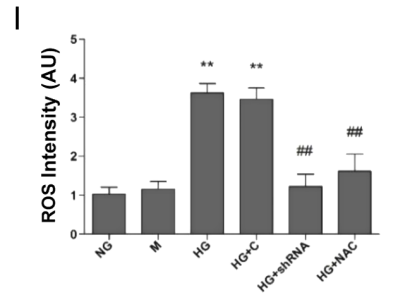

Figure 2

Effects of NLRP3 shRNA plasmid transfection on HG-induced activation of NLRP3 inflammasome and ROS production in HK-2 cells. (A) The protein expression of NLRP3 inflammasome, IL1B and IL18 was analyzed by Western blot $(n=6)$. (B) The quantitative analysis of NLRP3 inflammasome protein level $(n=6)$. (C) The mRNA expression of NLRP3 inflammasome was analyzed by RT-qPCR $(n=6)$. (D and E) The quantitative analysis of protein level of IL1B and IL18 $(n=6)$. (F and G) The mRNA expression of IL1B and IL18 was analyzed by RT-qPCR $(n=6)$. (H) Mitochondrial ROS were detected by the confocal microscope $(n=6)$. (I) The quantification of mitochondrial ROS intensity. NG: 5.6 mM D-glucose; HG: 30 mM D-glucose; HG + C: HG + control shRNA plasmid; $\mathrm{HG}+$ shRNA: $\mathrm{HG}+N L R P 3$ shRNA plasmid; $\mathrm{HG}+\mathrm{NAC}: \mathrm{HG}+\mathrm{N}$-acetylcysteine $(5 \mathrm{mM})$. Values are expressed as means \pm s.D. $* P<0.05, * * P<0.01$ vs $\mathrm{NG}$, $\# P<0.05, \# P<0.01$ vs $H G+C$.

http://jme.endocrinology-journals.org https://doi.org/10.1530/JME-18-0069 (c) 2018 Society for Endocrinology Published by Bioscientifica Ltd. Printed in Great Britain 
A

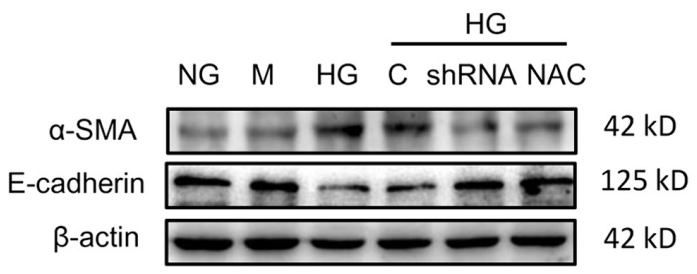

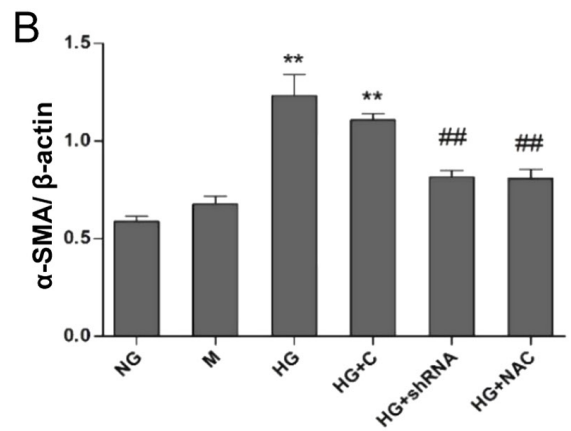

E

C

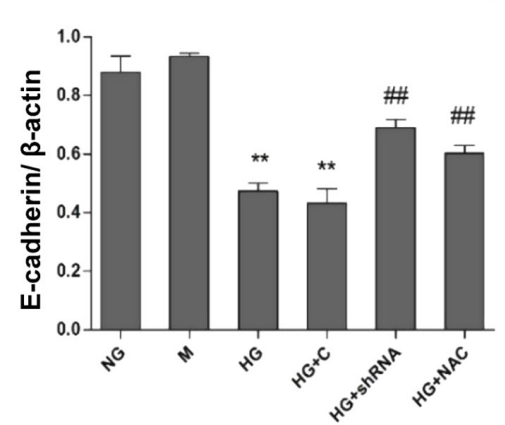

F

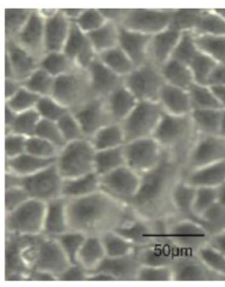

NG
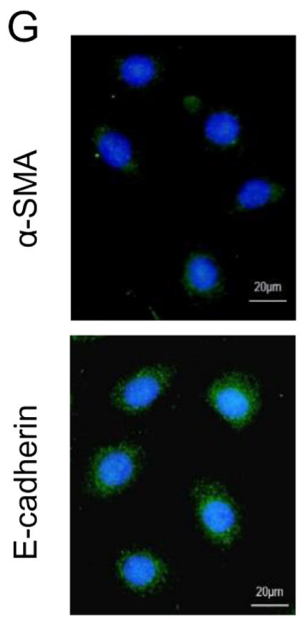

NG

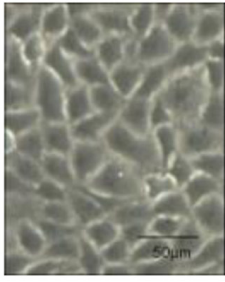

M
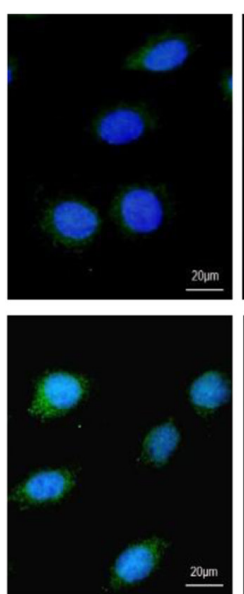

M
D
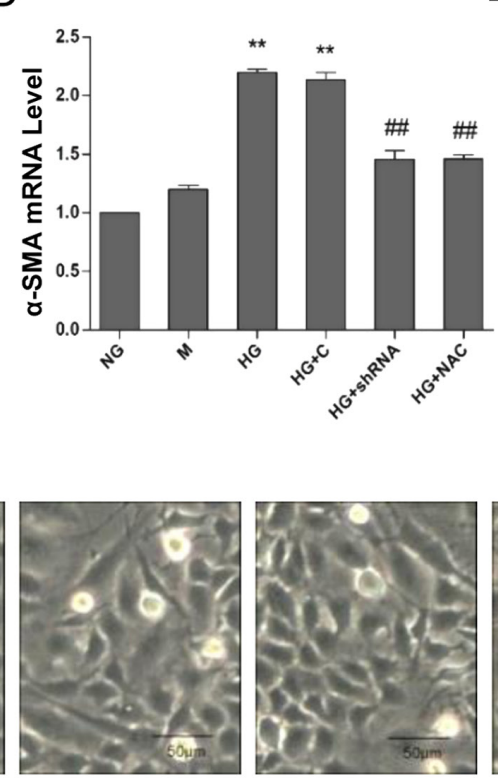

HG
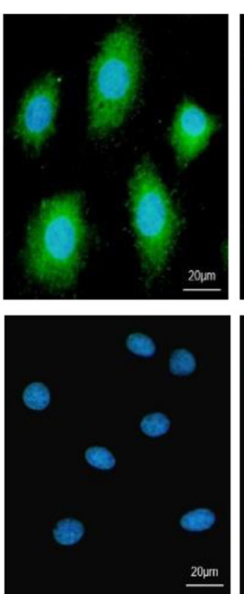

HG

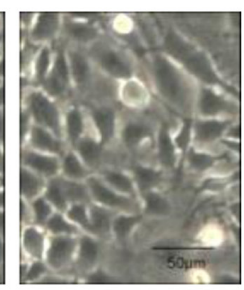

$\mathrm{HG}+\mathrm{C}$
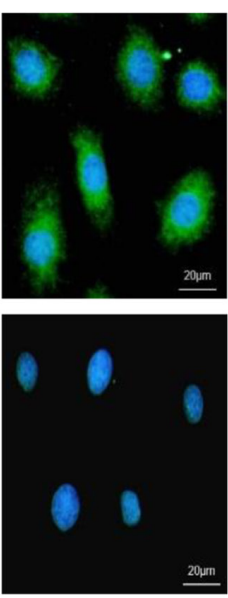

$\mathrm{HG}+\mathrm{C}$
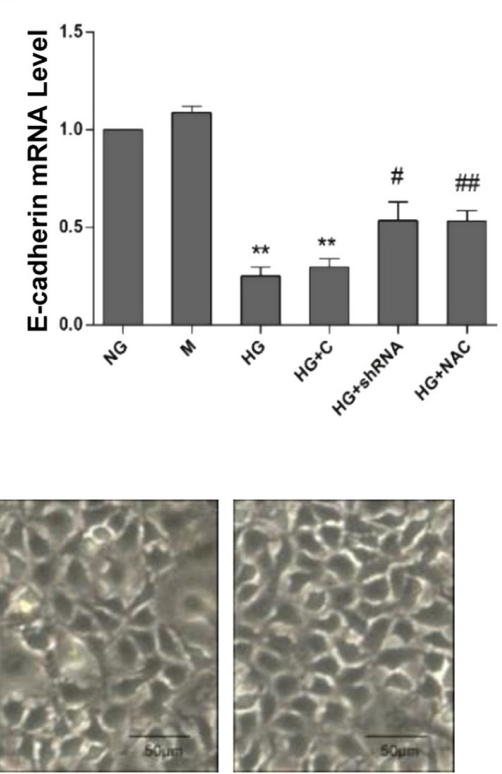

HG+shRNA
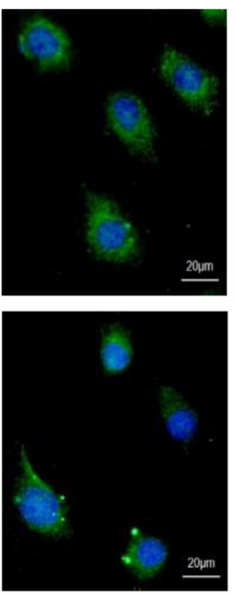

HG+shRNA
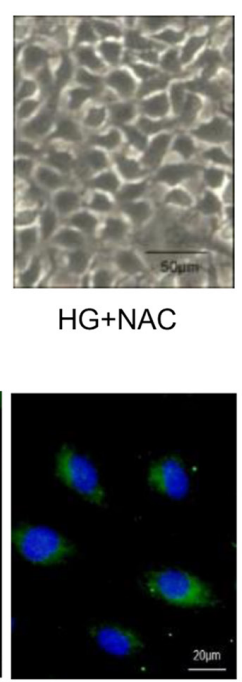

$\mathrm{HG}+\mathrm{NAC}$

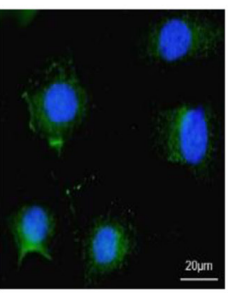

$H G+N A C$

\section{Figure 3}

Effects of NLRP3 silencing on HG-induced EMT in HK-2 cells. (A, B and C) The expression levels of $\alpha$-SMA and E-cadherin protein were detected by Western blot $(n=6)$. (D and E) The mRNA levels of $\alpha$-SMA and E-cadherin were analyzed by RT-qPCR $(n=6)$. (F) Morphological changes of HK-2 cells cultured under different conditions were analyzed by the inverted microscope. (G) The effect of NLRP3 shRNA plasmid on the expression of $\alpha$-SMA and E-cadherin in HK-2 cells was detected by immunofluorescence. NG: $5.6 \mathrm{mM}$ D-glucose; HG: $30 \mathrm{mM}$ D-glucose; HG + C: HG + control shRNA plasmid; $\mathrm{HG}+$ shRNA: $\mathrm{HG}+N L R P 3$ shRNA plasmid; $\mathrm{HG}+\mathrm{NAC}: \mathrm{HG}+\mathrm{N}$-acetylcysteine $(5 \mathrm{mM})$. Values are expressed as means \pm s.D. ${ }^{* *} P<0.01 \mathrm{vs} N \mathrm{NG},{ }^{*} P<0.05, \# \#<0.01$ vs $H G+C$. 
with the results of Western blotting (Fig. 3D and E). In addition, immunofluorescence detection of E-cadherin and $\alpha$-SMA confirmed the results of Western blotting (Fig. 3G).

\section{Knockdown of NLRP3 prevents HG-induced EMT through inhibiting phosphorylation of SMAD3, P38 MAPK and ERK1/2}

Previous studies demonstrated that P38 MAPK, ERK1/2 and SMAD3 were involved in HG-induced EMT in renal tubular epithelial cells (Lan 2012, Wei et al. 2013). It remains unclear whether knockdown of NLRP3 suppressed HG-induced activation of SMAD3, P38 MAPK or ERK1/2. The phosphorylation levels of SMAD3, P38 MAPK and ERK1/2 were markedly upregulated in the HG group, compared with those of the NG group; while the increased phosphorylation levels of SMAD3, P38 MAPK and ERK1/2 were evidently downregulated by NLRP3 shRNA plasmid transfection or NAC treatment (Fig. 4A, B, C and D).

\section{HG-induced NLRP3 inflammasome activation might be mediated by P38 MAPK and ERK1/2}

In order to investigate whether P38 MAPK or ERK1/2 signal pathway affected the activation of NLRP3 inflammasome induced by HG, we preincubated the HK-2 cells with a specific P38 MAPK inhibitor SB203580 $(10 \mu \mathrm{M})$ or ERK1/2 inhibitor PD98059 $(50 \mu \mathrm{M})$ for $0.5 \mathrm{~h}$, and then the cells were incubated with HG in the presence of SB203580 or PD98059 for $48 \mathrm{~h}$. Interestingly, the HG-induced activation of NLRP3 inflammasome, as well as the secretion of IL1B and IL18 could be inhibited by SB203580 or PD98059 (Fig. 4E, F, G and H), indicating that P38 MAPK and ERK1/2 signaling pathway might be involved in HG-induced activation of NLRP3 inflammasome in renal tubular epithelial cells.

\section{TGFB1 induces the activation of NLRP3} inflammasome in ROS-dependent manner

To explore the role of TGFB1 on NLRP3 inflammasome activation, HK-2 cells were treated with TGFB1 $(4 \mathrm{ng} / \mathrm{mL})$ for $48 \mathrm{~h}$. Compared with the $\mathrm{N}$ group, the expression levels of NLRP3, ASC and Caspase-1 were upregulated in TGFB1 group; meanwhile, the increased levels of NLRP3, ASC and Caspase- 1 were significantly alleviated through NLRP3 silencing or NAC (Fig. 5A, B and C). Besides, the protein and mRNA levels of IL1B and IL18 also showed an elevation in TGFB1 and TGFB1 $+C$ group, which descended by NLRP3 silencing or NAC (Fig. 5A, D, E, F and G). Next, we detected the ROS generation of different groups in HK-2 cells by the confocal microscope. TGFB1 strongly stimulated an upregulation of ROS generation, which was remarkably reversed by NLRP3 interference or preincubation with NAC (Fig. 5H and I). Hence, these results indicate that NLRP3 inflammasome activation induced by TGFB1 is ROS dependent.

\section{NLRP3 silencing prevents TGFB1-induced EMT via ROS}

Eventually, we investigated the effect of NLRP3 interference on the TGFB1-induced EMT in vitro. HK-2 cells were transfected with NLRP3 shRNA plasmid or control shRNA plasmid separately, and then cells were treated with TGFB1 for $48 \mathrm{~h}$. Both protein and mRNA expression of $\alpha$ SMA were significantly increased in HK-2 cells exposed to TGFB1, while the levels of epithelial marker E-cadherin were blocked (Fig. 6A, B, C, D and E). However, the alterations induced by TGFB1 in HK-2 cells were significantly attenuated by NLRP3 silencing or NAC (Fig. 6A, B, C, D and $\mathrm{E})$. Besides, the results of immunofluorescence were consistent with that of Western blot above (Fig. 6G). Then, we utilized an inverted microscope to observe morphologic changes of HK-2 cells in various groups. A cuboidal shape was seen in HK-2 cells of $\mathrm{N}$ group, whereas a treatment with TGFB1 made their shape turn into spindlelike (Fig. 6F). However, NLRP3 interference or NAC prevented these alterations induced by TGFB1 (Fig. 6F). Taken together, these data demonstrate that knockdown of NLRP3 inhibited TGFB1-induced EMT in HK-2 cells via ROS.

\section{Discussion}

As for diabetic nephropathy, tubulointerstitial lesions were usually regarded as one of the most important elements that could lead to renal fibrosis, rather than glomerular lesions and EMT (Morcos et al. 2002). Excessive deposition of extracellular matrix (ECM) of the tubulointerstitium and glomerular mesangium is intimately associated with the progressive decline of renal function in diabetes (Liu 2004, Fioretto \& Mauer 2007). EMT, the epithelialmesenchymal transition, which is induced by HG or TGFB1, has been reported to be accommodated via ROS (Liu 2004, Lee et al. 2013). In this study, we explored the effect of NLRP3 interference on HG-induced EMT in HK-2 cells in vitro. We found that $\alpha$-SMA was upregulated and E-cadherin was downregulated in HK-2 cells exposed to 
A

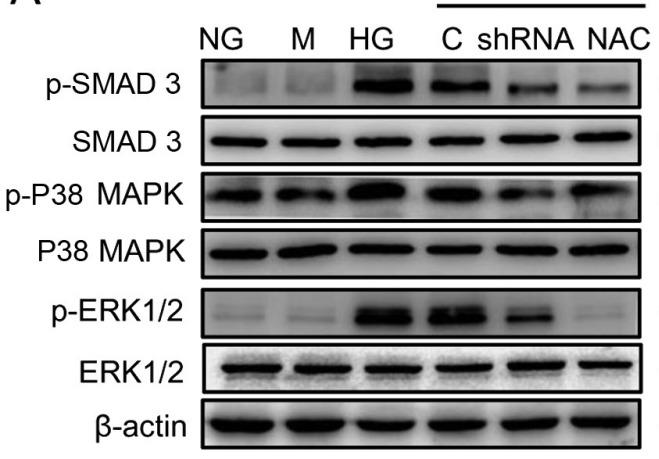

HG $48 \mathrm{kD}$ $48 \mathrm{kD}$ $43 \mathrm{kD}$ $40 \mathrm{kD}$ $42,44 \mathrm{kD}$ $42,44 \mathrm{kD}$ $42 \mathrm{kD}$

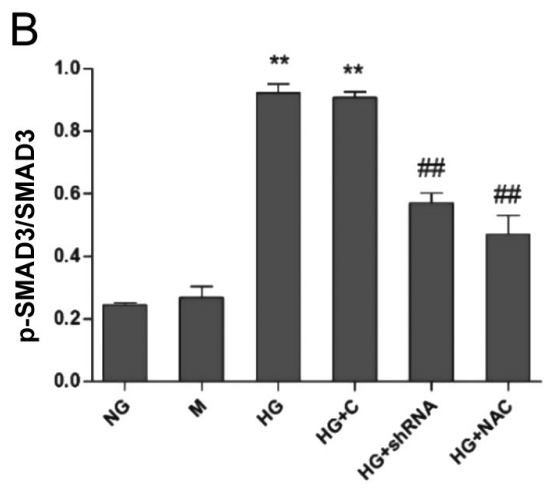

E

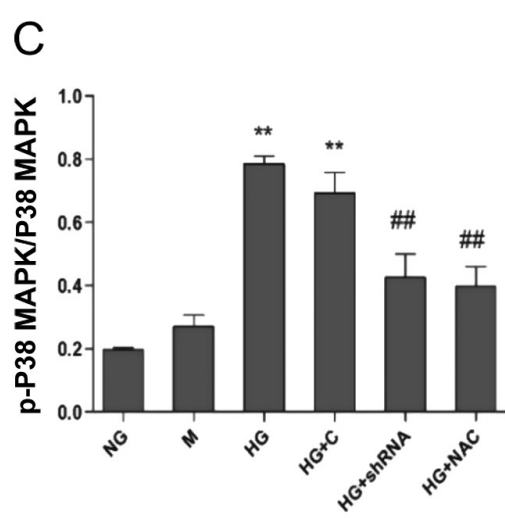

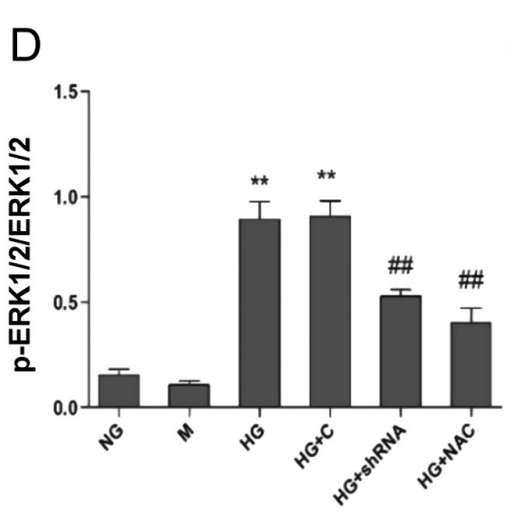

G

$\mathrm{H}$

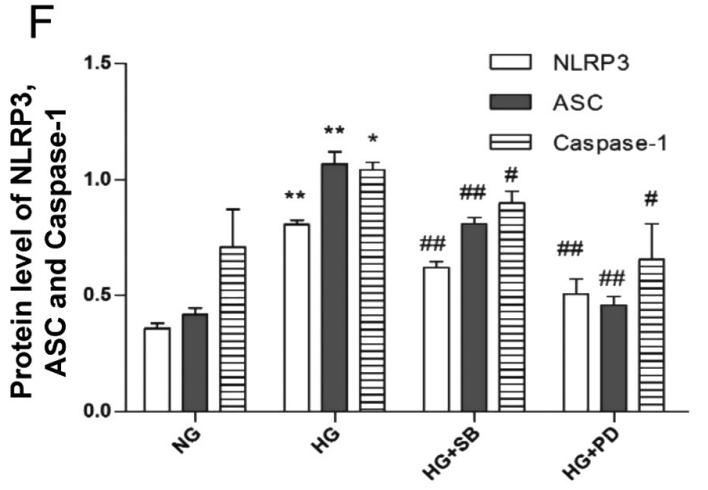

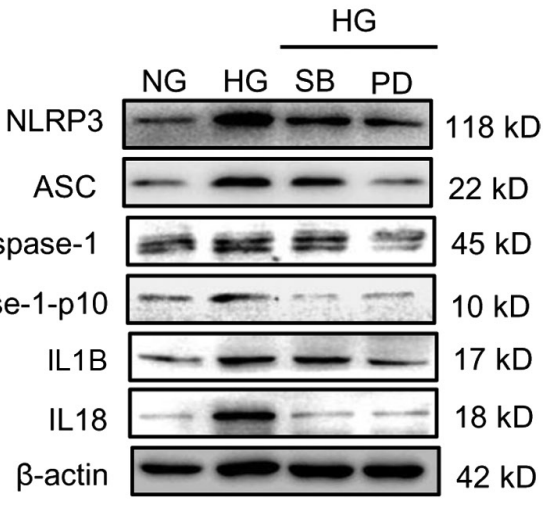

Figure 4

Effect of NLRP3 interference on HG-induced activation of SMAD3, P38 MAPK and ERK1/2 as well as the effect of SB203580 and PD98059 on NLRP3 inflammasome. (A, B, C and D) The expression levels of p-SMAD3, SMAD3, p-P38 MAPK, P38 MAPK, pERK1/2 and ERK1/2 were analyzed by Western blot $(n=6)$. NG: $5.6 \mathrm{mM}$ D-glucose; HG: $30 \mathrm{mM}$ D-glucose; HG + C: HG + control shRNA plasmid; HG + shRNA: HG + NLRP3 shRNA plasmid; HG + NAC: $\mathrm{HG}+\mathrm{N}$-acetylcysteine $(5 \mathrm{mM})$. (E, F, G and H) The expression level of NLRP3 inflammasome and the maturation of IL1B and IL18 was analyzed by Western blot ( $n=4)$. NG: $5.6 \mathrm{mM}$ D-glucose, HG: $30 \mathrm{mM}$ D-glucose, HG + SB: HG + SB203580 (10 $\mu \mathrm{M})$ and HG + PD: HG + PD98059 (50 $\mu$ M). Values are expressed as means \pm s.D. ${ }^{*} P<0.05, * * P<0.01$ vs NG, ${ }^{*} P<0.05, \# P<0.01$, vs $\mathrm{HG}+\mathrm{C}$.

elevated glucose conditions within a time-dependent manner. Knockdown of NLRP3 inhibits HG-induced EMT and activation of SMAD3, P38 MAPK and ERK1/2 in HK-2 cells. We also found that NLRP3 interference inhibited EMT induced by TGFB1.
The NLRP3 inflammasome is a protein complex in cytoplasm, which is activated upon signs of cellular 'danger' to trigger innate immune defenses (Ding et al. 2016). When it comes to probing cellular stress, NLRP3 could recruit the adaptor protein ASC and pro-Caspase-1, 

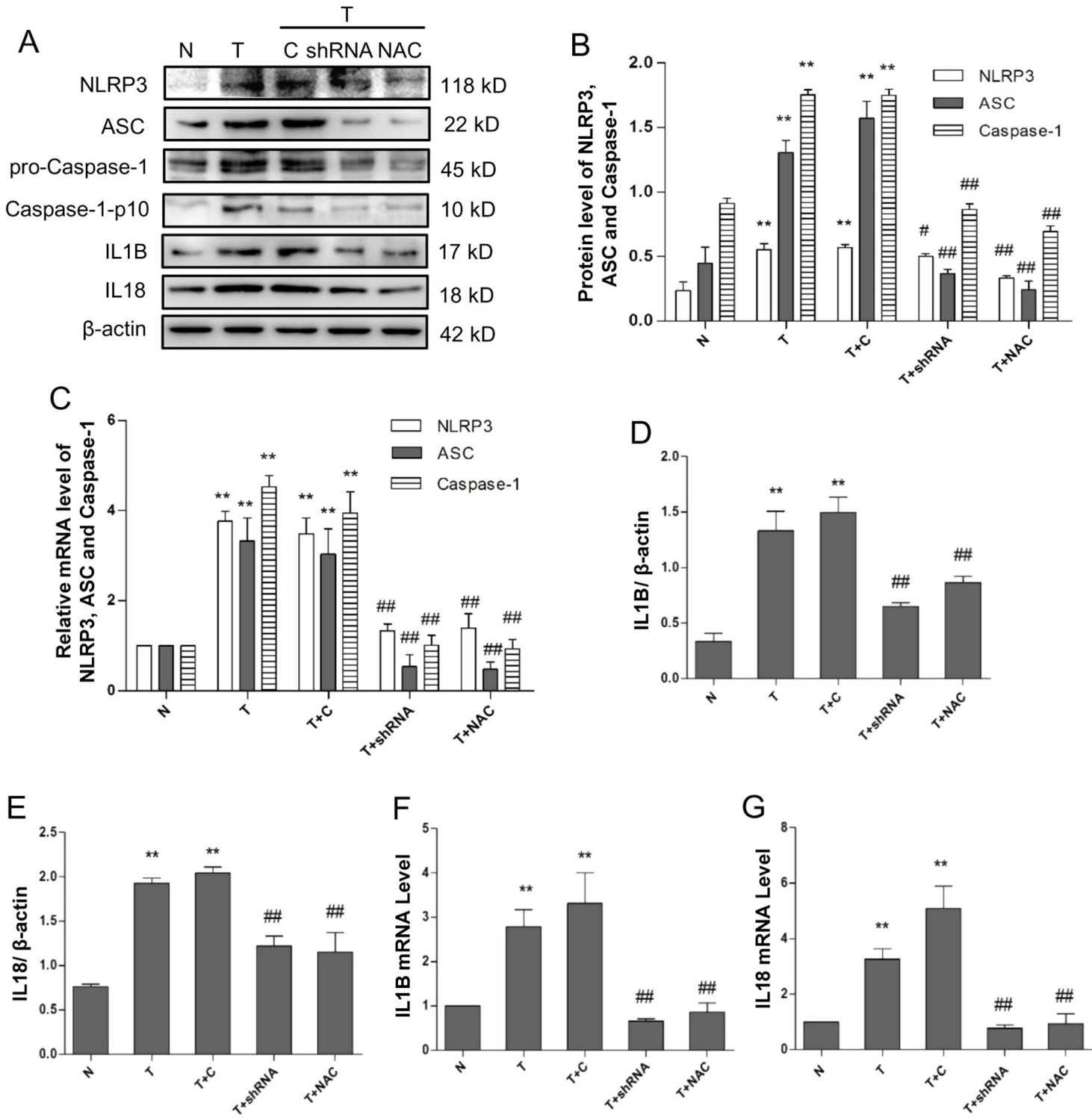

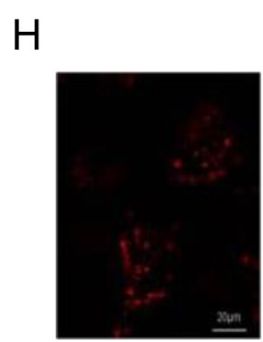

N

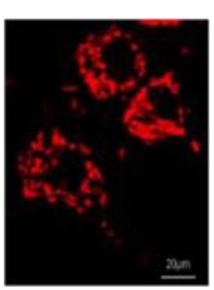

$\mathrm{T}$

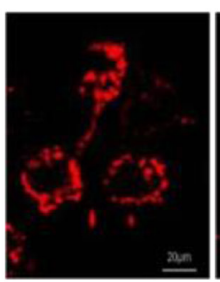

$\mathrm{T}+\mathrm{C}$

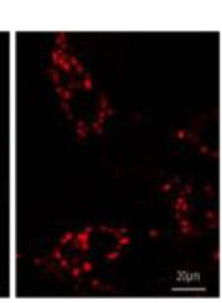

T+shRNA

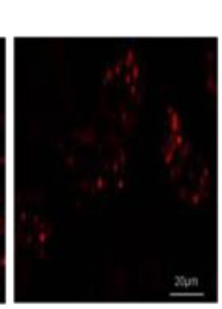

$\mathrm{T}+\mathrm{NAC}$

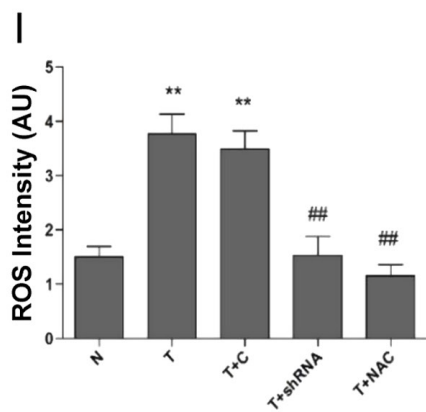

Figure $\mathbf{5}$

The effect of TGFB1 on the activation of NLRP3 inflammasome and ROS production in HK-2 cells. HK-2 cells were exposed to 4 ng/mL TGFB1 under different conditions for 48h. (A) The protein expression of NLRP3 inflammasome, IL1B and IL18 was detected by Western blot ( $n=5$ ). (B) The quantitative analysis of NLRP3 inflammasome protein level $(n=5)$. (C) The mRNA expression of NLRP3 inflammasome was analyzed by RT-qPCR $(n=5)$.

( $D$ and E) The quantitative analysis of protein level of IL1B and IL18 $(n=5)$. (F and G) The mRNA expression of IL1B and IL18 was analyzed by RT-qPCR $(n=5)$. (H) Mitochondrial ROS were detected by the confocal microscope $(n=5)$. (I) The quatification of mitochondrial ROS intensity. N: normal control; T: TGFB1 (4 ng/mL); T + C: TGFB1 (4ng/mL) + control shRNA plasmid; T+ shRNA: TGFB1 $(4 \mathrm{ng} / \mathrm{mL})+N L R P 3$ shRNA plasmid; T+ NAC: TGFB1 $(4 \mathrm{ng} / \mathrm{mL})+\mathrm{N}$-acetylcysteine $(5 \mathrm{mM})$. Values are expressed as means \pm S.D. ${ }^{*} P<0.01$ vs $\mathrm{N}, \# P<0.05,{ }^{\#} P<0.01$ vs $\mathrm{T}+\mathrm{C}$. 
A

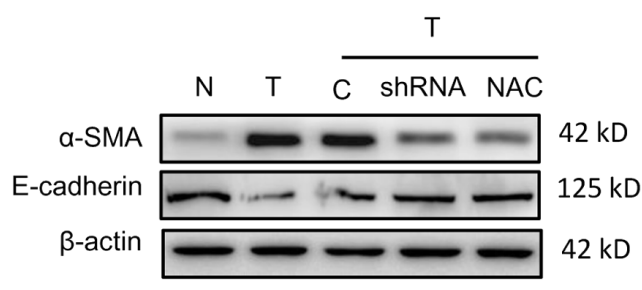

B

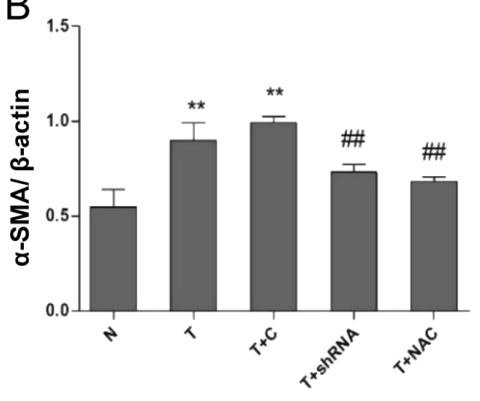

C

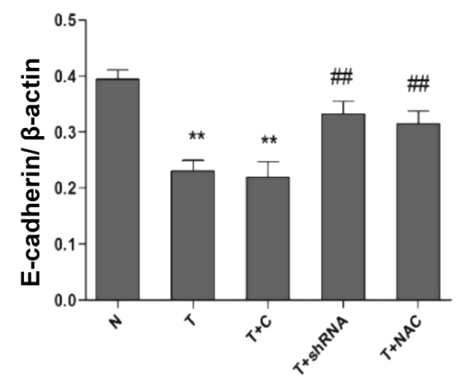

D

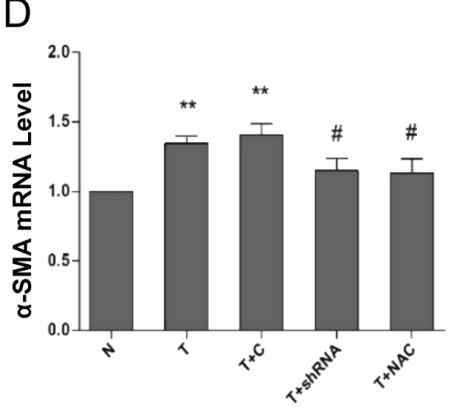

E

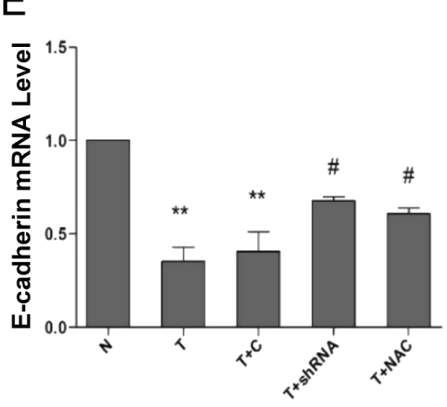

F

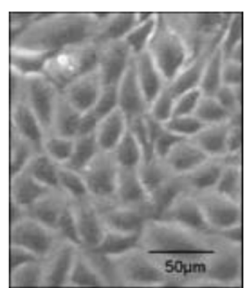

N
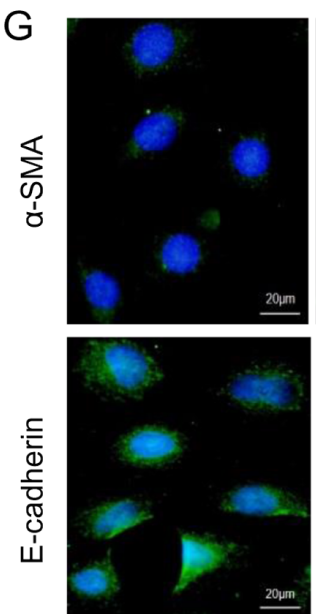

N

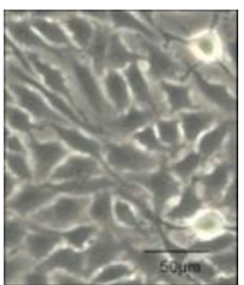

T
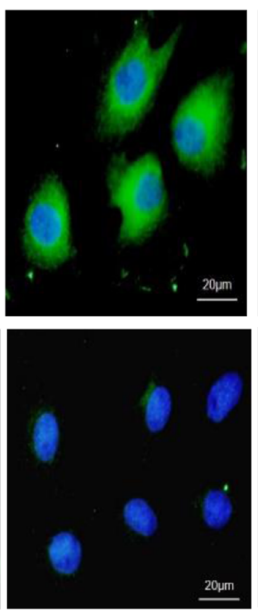

T

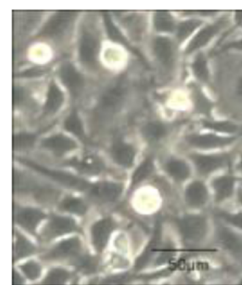

$T+C$
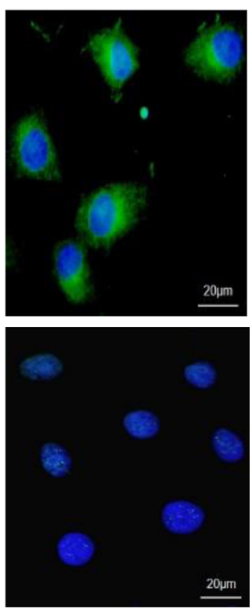

$\mathrm{T}+\mathrm{C}$

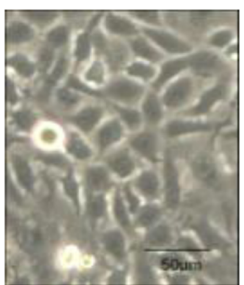

T+shRNA
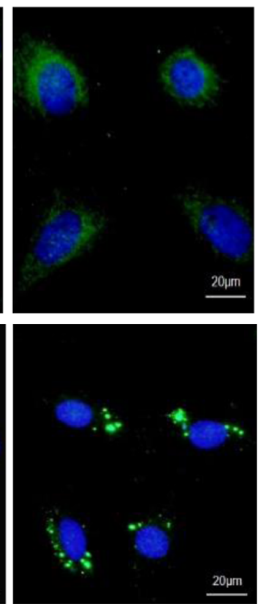

T+shRNA

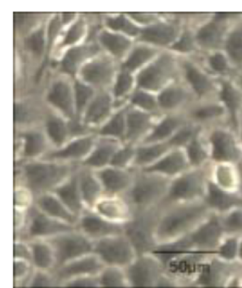

$\mathrm{T}+\mathrm{NAC}$
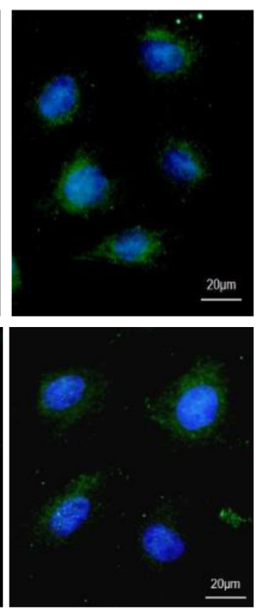

T+NAC

Figure 6

The effect of NLRP3 silencing on TGFB1-induced EMT in HK-2 cells. HK-2 cells were exposed to $4 \mathrm{ng} / \mathrm{mL}$ TGFB1 under different conditions for $48 \mathrm{~h}$. (A, B and C) The protein levels of $\alpha$-SMA and E-cadherin were detected by Western blot $(n=5)$. (D and E) The mRNA expression levels of $\alpha$-SMA and E-cadherin were analyzed by RT-qPCR $(n=5)$. (F) Morphological changes of HK-2 cells were analyzed by the inverted microscope. (G) The effect of NLRP3 shRNA plasmid on the expression of $\alpha$-SMA and E-cadherin in HK-2 cells was detected by immunofluorescence. $\mathrm{N}$ : normal control; T: TGFB1 (4 ng/mL); T+C: TGFB1 $(4 \mathrm{ng} / \mathrm{mL})+$ control shRNA plasmid; T + shRNA: TGFB1 $(4 \mathrm{ng} / \mathrm{mL})+N L R P 3$ shRNA plasmid; $\mathrm{T}+\mathrm{NAC}$ : TGFB1 $(4 \mathrm{ng} / \mathrm{mL})+\mathrm{N}$-acetylcysteine $(5 \mathrm{mM})$. Values are expressed as means \pm s.D. ${ }^{*} P P<0.01$ vs $N,{ }^{*} P<0.05, \# P<0.01$ vs $T+C$. 
resulting in Caspase-1 activation and the processing of cytoplasmic targets, including IL1B and IL18 (Schroder \& Tschopp 2010, Zhou et al. 2011). Lately, the NLRP3 inflammasome was demonstrated to participate in the pathogenesis of renal disease (Ding et al. 2016). Moreover, NLRP3 deficiency was shown to mitigate renal inflammation and fibrosis in a model of renal tubular injury (Iyer et al. 2009, Zhuang et al. 2014). Existing research demonstrated that NLRP3 protein expression, cleavage of Caspase-1, along with the maturation of IL1B and IL18 significantly increased in HK-2 cells after HG stimulation (Chen et al. 2013). Also, it has been reported that ROS production contributes to HG-induced NLRP3 inflammasome activation in MVECs (Chen et al. 2016). In this article, we showed that HG promoted the expression of NLRP3 protein and mRNA in a timedependent manner in HK-2 cells, and that treatment with the antioxidant, NAC, could significantly suppress NLRP3 expression induced by HG, suggesting that ROS may be involved in HG-induced NLRP3 expression in HK-2 cells. ROS mediated HG-induced EMT in renal tubular cells has been documented (Ha \& Lee 2003, Lee et al. 2013). In the present study, we found that transfection with NLRP3 shRNA plasmid or treatment with NAC notably protected the renal tubular cells from HG-induced EMT and ROS generation. These results indicate that NLRP3 interference might prevent HG-induced EMT via the reduction of ROS.

Till now, the potential molecular mechanisms still remain sealed. Varied forms of signaling pathways are considered to be relevant with the regulation of EMT, for instance, P38 MAPK, ERK1/2 and TGFB1/SMAD (Schramek et al. 2003, Liu 2004, Rhyu et al. 2005, Hou et al. 2015). Previous studies demonstrated that HG-induced EMT blocked by procyanidin and zinc was associated with P38 MAPK and ERK signaling activation (Li et al. 2015a, Zhang et al. 2015). Lv et al. (2011) showed that P38 MAPK played really an important role in the HG-induced EMT in human renal tubular cells. In our study, we confirmed that HG not simply reduced E-cadherin expression and increased $\alpha$-SMA expression, but also activated the phosphorylation levels of SMAD3, P38 MAPK and ERK1/2 in HK-2 cells. In order to testify the role of NLRP3, we conducted the transfection experiment against NLRP3 in the activation of SMAD3, P38 MAPK and ERK1/2 induced by HG. An NLRP3 shRNA plasmid was utilized to transfect with HK-2 cells, as a result, this was ultimately proven to be able to prevent HG-induced activation of SMAD3, P38 MAPK and ERK1/2. Simultaneously, HG-induced SMAD3, P38 MAPK and ERK1/2 activation could also be inhibited by NAC treatment. Interestingly, when we used P38
MAPK inhibitor (SB203580) or ERK inhibitor (PD98059) in HK-2 cells exposed to HG, which were similar to the antioxidant NAC, we found that HG-induced NLRP3 inflammasome activation could be suppressed by them, further suggesting the role of ROS-MAPK in NLRP3 inflammasome activation. In short, the results above implicated that knockdown of NLRP3 mitigates HG-induced EMT via ROS-MAPK signaling pathway in HK-2 cells, and P38 MAPK and ERK1/2 might mediate the activation of NLRP3 inflammasome.

EMT is involved in the process of renal fibrosis, which is a major contributor in this pathogenesis, and that TGFB1 is a crucial mediator in EMT (Zeisberg \& Neilson 2010). As a matter of fact, TGFB1 plays a critical role in the process of diabetic nephropathy and is well recognized as a profibrotic and inflammatory cytokine in the kidney (Qi et al. 2006, Zeisberg \& Neilson 2010, Lan 2012). It has been reported that ROS has a great impact on tubulointerstitial fibrosis and EMT induced by TGFB1 (Rhyu et al. 2005, Samarakoon et al. 2013, Liu et al. 2016). Our recent study demonstrated that TGFB1 induced EMT and the generation of ROS, and treatment with NAC, the antioxidant, could effectively prevent EMT induced by TGFB1 in HK-2 cells (Wei et al. 2013). Analogously, we found that TGFB1 could induce EMT and ROS generation, and treatment with NAC could markedly prevent EMT induced by TGFB1 in HK-2 cells. Moreover, we also found that NLRP3 silencing could suppress ROS generation and TGFB1-induced EMT. Thus, our data implicate that NLRP3 silencing may ameliorate TGFB1-induced EMT via inhibition of ROS generation. Besides, we focused further exploration on the effect of TGFB1 on the expression of NLRP3 in vitro. In the present study, we found that both mRNA and protein levels were facilitated by TGFB1 in HK-2 cells, and the activation of NLRP3 inflammasome was significantly suppressed by pretreatment with NAC. Our results are consistent with a previous observation that the level of NLRP3 was upregulated by TGFB1 in colon cancer cells (Wang et al. 2016). Whereas a NLRP3 inflammasome-independent pathway has been proposed, which involves the TGFB signaling mechanism (Wang et al. 2013); and another article reported that inflammasome-related Caspase- 1 and non-inflammasome related phospho-SMAD 2/3 pathways both associated with uric acid-induced EMT, inflammation and fibrosis in kidney (Romero et al. 2017).

Taken together, all these data above verify that NLRP3 silencing withstood EMT induced by HG via suppression of ROS generation, activation of SMAD3, P38 MAPK and ERK1/2. Also, NLRP3 interference could prevent 
TGFB1-induced EMT via ROS. Hence, we may conjecture that NLRP3 could become a promising target for diabetic nephropathy.

\section{Declaration of interest}

The authors declare that there is no conflict of interest that could be perceived as prejudicing the impartiality of the research reported.

\section{Funding}

This study was supported by grants from the National Natural Science Foundation of China (NO. 81270804; 81470966) and China Postdoctoral Science Foundation funded project (2014M561199).

\section{References}

Bottinger EP \& Bitzer M 2002 TGF-beta signaling in renal disease. Journal of the American Society of Nephrology 13 2600-2610. (https://doi. org/10.1097/01.ASN.0000033611.79556.AE)

Burns WC, Twigg SM, Forbes JM, Pete J, Tikellis C, Thallas-Bonke V, Thomas MC, Cooper ME \& Kantharidis P 2006 Connective tissue growth factor plays an important role in advanced glycation end product-induced tubular epithelial-to-mesenchymal transition: implications for diabetic renal disease. Journal of the American Society of Nephrology 17 2484-2494. (https://doi.org/10.1681/ ASN.2006050525)

Chen J, Chen JK \& Harris RC 2012 Angiotensin II induces epithelial-tomesenchymal transition in renal epithelial cells through reactive oxygen species/Src/caveolin-mediated activation of an epidermal growth factor receptor-extracellular signal-regulated kinase signaling pathway. Molecular and Cellular Biology 32 981-991. (https://doi. org/10.1128/MCB.06410-11)

Chen K, Zhang J, Zhang W, Zhang J, Yang J, Li K \& He Y 2013 ATPP2X4 signaling mediates NLRP3 inflammasome activation: a novel pathway of diabetic nephropathy. International Journal of Biochemistry and Cell Biology 45 932-943. (https://doi.org/10.1016/j. biocel.2013.02.009)

Chen Y, Wang L, Pitzer AL, Li X, Li PL \& Zhang Y 2016 Contribution of redox-dependent activation of endothelial Nlrp3 inflammasomes to hyperglycemia-induced endothelial dysfunction. Journal of Molecular Medicine 94 1335-1347. (https://doi.org/10.1007/s00109-016-1481-5)

Ding W, Guo H, Xu C, Wang B, Zhang M \& Ding F 2016 Mitochondrial reactive oxygen species-mediated NLRP3 inflammasome activation contributes to aldosterone-induced renal tubular cells injury. Oncotarget 7 17479-17491. (https://doi.org/10.18632/ oncotarget.13871)

Dostert C, Petrilli V, Van Bruggen R, Steele C, Mossman BT \& Tschopp J 2008 Innate immune activation through Nalp3 inflammasome sensing of asbestos and silica. Science 320 674-677. (https://doi. org/10.1126/science.1156995)

Dostert C, Guarda G, Romero JF, Menu P, Gross O, Tardivel A, Suva ML, Stehle JC, Kopf M, Stamenkovic I, et al. 2009 Malarial hemozoin is a Nalp3 inflammasome activating danger signal. PLoS ONE 4 e6510. (https://doi.org/10.1371/journal.pone.0006510)

Fan Y, Li X, Xiao W, Fu J, Harris RC, Lindenmeyer M, Cohen CD, Guillot N, Baron MH, Wang N, et al. 2015 BAMBI elimination enhances alternative TGF-beta signaling and glomerular dysfunction in diabetic mice. Diabetes 64 2220-2233. (https://doi.org/10.2337/ db14-1397)

Fioretto P \& Mauer M 2007 Histopathology of diabetic nephropathy. Seminars in Nephrology 27 195-207. (https://doi.org/10.1016/j. semnephrol.2007.01.012)
Forbes JM, Coughlan MT \& Cooper ME 2008 Oxidative stress as a major culprit in kidney disease in diabetes. Diabetes 57 1446-1454. (https://doi.org/10.2337/db08-0057)

Ha H \& Lee HB 2003 Reactive oxygen species and matrix remodeling in diabetic kidney. Journal of the American Society of Nephrology 14 S246-S249. (https://doi.org/10.1097/01.ASN.0000077411.98742.54)

Ha H, Yu MR, Choi YJ, Kitamura M \& Lee HB 2002 Role of high glucose-induced nuclear factor-kappaB activation in monocyte chemoattractant protein-1 expression by mesangial cells. Journal of the American Society of Nephrology 13 894-902.

Hou Y, Wu M, Wei J, Ren Y, Du C, Wu H, Li Y \& Shi Y 2015 CD36 is involved in high glucose-induced epithelial to mesenchymal transition in renal tubular epithelial cells. Biochemical and Biophysical Research Communications 468 281-286. (https://doi.org/10.1016/j. bbrc.2015.10.112)

Iyer SS, Pulskens WP, Sadler JJ, Butter LM, Teske GJ, Ulland TK, Eisenbarth SC, Florquin S, Flavell RA, Leemans JC, et al. 2009 Necrotic cells trigger a sterile inflammatory response through the Nlrp3 inflammasome. PNAS 106 20388-20393. (https://doi. org/10.1073/pnas.0908698106)

Jaimes EA, Galceran JM \& Raij L 1998 Angiotensin II induces superoxide anion production by mesangial cells. Kidney International $\mathbf{5 4}$ 775-784. (https://doi.org/10.1046/j.1523-1755.1998.00068.x)

Kim SM, Lee SH, Kim YG, Kim SY, Seo JW, Choi YW, Kim DJ, Jeong KH, Lee TW, Ihm CG, et al. 2015 Hyperuricemia-induced NLRP3 activation of macrophages contributes to the progression of diabetic nephropathy. American Journal of Physiology-Renal Physiology $\mathbf{3 0 8}$ F993-F1003. (https://doi.org/10.1152/ajprenal.00637.2014)

Lan HY 2012 Transforming growth factor-beta/Smad signalling in diabetic nephropathy. Clinical and Experimental Pharmacology and Physiology 39 731-738. (https://doi. org/10.1111/j.1440-1681.2011.05663.x)

Lee YJ \& Han HJ 2010 Troglitazone ameliorates high glucose-induced EMT and dysfunction of SGLTs through PI3K/Akt, GSK-3beta, Snail1, and beta-catenin in renal proximal tubule cells. American Journal of Physiology-Renal Physiology 298 F1263-F1275. (https://doi. org/10.1152/ajprenal.00475.2009)

Lee JH, Kim JH, Kim JS, Chang JW, Kim SB, Park JS \& Lee SK 2013 AMPactivated protein kinase inhibits TGF-beta-, angiotensin II-, aldosterone-, high glucose-, and albumin-induced epithelialmesenchymal transition. American Journal of Physiology-Renal Physiology 304 F686-E697. (https://doi.org/10.1152/ ajprenal.00148.2012)

Li D, Zhao T, Meng J, Jing Y, Jia F \& He P 2015a Procyanidin B2 inhibits high glucoseinduced epithelialmesenchymal transition in HK2 human renal proximal tubular epithelial cells. Molecular Medicine Reports 12 8148-8154. (https://doi.org/10.3892/mmr.2015.4445)

Li X, Liu S, Luo J, Liu A, Tang S, Liu S, Yu M \& Zhang Y $2015 b$ Helicobacter pylori induces IL-1beta and IL-18 production in human monocytic cell line through activation of NLRP3 inflammasome via ROS signaling pathway. Pathogens and Disease 73 1-8.

Liu Y 2004 Epithelial to mesenchymal transition in renal fibrogenesis: pathologic significance, molecular mechanism, and therapeutic intervention. Journal of the American Society of Nephrology 15 1-12. (https://doi.org/10.1097/01.ASN.0000106015.29070.E7)

Liu Y, Yuan X, Li W, Cao Q \& Shu Y 2016 Aspirin-triggered resolvin D1 inhibits TGF-beta1-induced EMT through the inhibition of the mTOR pathway by reducing the expression of PKM2 and is closely linked to oxidative stress. International Journal of Molecular Medicine 38 1235-1242. (https://doi.org/10.3892/ijmm.2016.2721)

Loeffler I, Liebisch M \& Wolf G 2012 Collagen VIII influences epithelial phenotypic changes in experimental diabetic nephropathy. American Journal of Physiology-Renal Physiology 303 F733-F745. (https://doi. org/10.1152/ajprenal.00212.2012)

Lv ZM, Wang Q, Wan Q, Lin JG, Hu MS, Liu YX \& Wang R 2011 The role of the p38 MAPK signaling pathway in high glucose-induced epithelial-mesenchymal transition of cultured human renal tubular 
epithelial cells. PLoS ONE 6 e22806. (https://doi.org/10.1371/journal. pone.0022806)

Morcos M, Sayed AA, Bierhaus A, Yard B, Waldherr R, Merz W, Kloeting I, Schleicher E, Mentz S, Abd el Baki RF, et al. 2002 Activation of tubular epithelial cells in diabetic nephropathy. Diabetes 51 3532-3544. (https://doi.org/10.2337/diabetes.51.12.3532)

Nakahira K, Haspel JA, Rathinam VA, Lee SJ, Dolinay T, Lam HC, Englert JA, Rabinovitch M, Cernadas M, Kim HP, et al. 2011 Autophagy proteins regulate innate immune responses by inhibiting the release of mitochondrial DNA mediated by the NALP3 inflammasome. Nature Immunology 12 222-230. (https://doi. org/10.1038/ni.1980)

Nishikawa T, Edelstein D, Du XL, Yamagishi S, Matsumura T, Kaneda Y, Yorek MA, Beebe D, Oates PJ, Hammes HP, et al. 2000 Normalizing mitochondrial superoxide production blocks three pathways of hyperglycaemic damage. Nature $\mathbf{4 0 4}$ 787-790. (https://doi. org/10.1038/35008121)

Piek E, Moustakas A, Kurisaki A, Heldin CH \& ten Dijke P 1999 TGF(beta) type I receptor/ALK-5 and Smad proteins mediate epithelial to mesenchymal transdifferentiation in NMuMG breast epithelial cells. Journal of Cell Science 112 4557-4568.

Qi W, Chen X, Polhill TS, Sumual S, Twigg S, Gilbert RE \& Pollock CA 2006 TGF-beta1 induces IL- 8 and MCP-1 through a connective tissue growth factor-independent pathway. American Journal of PhysiologyRenal Physiology 290 F703-F709. (https://doi.org/10.1152/ ajprenal.00254.2005)

Rhyu DY, Yang Y, Ha H, Lee GT, Song JS, Uh ST \& Lee HB 2005 Role of reactive oxygen species in TGF-beta1-induced mitogen-activated protein kinase activation and epithelial-mesenchymal transition in renal tubular epithelial cells. Journal of the American Society of Nephrology 16 667-675. (https://doi.org/10.1681/ASN.2004050425)

Romero CA, Remor A, Latini A, De Paul AL, Torres AI \& Mukdsi JH 2017 Uric acid activates NRLP3 inflammasome in an in-vivo model of epithelial to mesenchymal transition in the kidney. Journal of Molecular Histology 48 209-218. (https://doi.org/10.1007/s10735-0179720-9)

Samarakoon R, Dobberfuhl AD, Cooley C, Overstreet JM, Patel S, Goldschmeding R, Meldrum KK \& Higgins PJ 2013 Induction of renal fibrotic genes by TGF-beta1 requires EGFR activation, p53 and reactive oxygen species. Cell Signaling 25 2198-2209. (https://doi. org/10.1016/j.cellsig.2013.07.007)

Schramek H, Feifel E, Marschitz I, Golochtchapova N, Gstraunthaler G \& Montesano R 2003 Loss of active MEK1-ERK1/2 restores epithelial phenotype and morphogenesis in transdifferentiated MDCK cells. American Journal of Physiology-Cell Physiology 285 C652-C661 (https://doi.org/10.1152/ajpcell.00463.2002)

Schroder K \& Tschopp J 2010 The inflammasomes. Cell 140 821-832. (https://doi.org/10.1016/j.cell.2010.01.040)

Shaw PJ, McDermott MF \& Kanneganti TD 2011 Inflammasomes and autoimmunity. Trends in Molecular Medicine 17 57-64. (https://doi. org/10.1016/j.molmed.2010.11.001)

Simonson MS 2007 Phenotypic transitions and fibrosis in diabetic nephropathy. Kidney International 71 846-854. (https://doi. org/10.1038/sj.ki.5002180)

Stutz A, Golenbock DT \& Latz E 2009 Inflammasomes: too big to miss. Journal of Clinical Investigation 119 3502-3511. (https://doi. org/10.1172/JCI40599)
Sun L, Xie P, Wada J, Kashihara N, Liu FY, Zhao Y, Kumar D, Chugh SS, Danesh FR \& Kanwar YS 2008 Rap1b GTPase ameliorates glucoseinduced mitochondrial dysfunction. Journal of the American Society of Nephrology 19 2293-2301. (https://doi.org/10.1681/ASN.2008030336)

Sun L, Kondeti VK, Xie P, Raparia K \& Kanwar YS 2011 Epac1-mediated, high glucose-induced renal proximal tubular cells hypertrophy via the Akt/p21 pathway. American Journal of Pathology 179 1706-1718. (https://doi.org/10.1016/j.ajpath.2011.06.035)

Vilaysane A, Chun J, Seamone ME, Wang W, Chin R, Hirota S, Li Y, Clark SA, Tschopp J, Trpkov K, et al. 2010 The NLRP3 inflammasome promotes renal inflammation and contributes to CKD. Journal of the American Society of Nephrology 21 1732-1744. (https://doi. org/10.1681/ASN.2010020143)

Wang W, Wang X, Chun J, Vilaysane A, Clark S, French G, Bracey NA, Trpkov K, Bonni S, Duff HJ, et al. 2013 Inflammasome-independent NLRP3 augments TGF-beta signaling in kidney epithelium. Journal of Immunology 190 1239-1249. (https://doi.org/10.4049/ jimmunol.1201959)

Wang J, Wen Y, Lv LL, Liu H, Tang RN, Ma KL \& Liu BC 2015 Involvement of endoplasmic reticulum stress in angiotensin II-induced NLRP3 inflammasome activation in human renal proximal tubular cells in vitro. Acta Pharmacologica Sinica 36 821-830. (https://doi.org/10.1038/aps.2015.21)

Wang H, Wang Y, Du Q, Lu P, Fan H, Lu J \& Hu R 2016 Inflammasomeindependent NLRP3 is required for epithelial-mesenchymal transition in colon cancer cells. Experimental Cell Research $\mathbf{3 4 2}$ 184-192. (https://doi.org/10.1016/j.yexcr.2016.03.009)

Wang T, Liu Y, Zou JF \& Cheng ZS 2017 Interleukin-17 induces human alveolar epithelial to mesenchymal cell transition via the TGF-beta1 mediated Smad2/3 and ERK1/2 activation. PLOS ONE 12 e0183972. (https://doi.org/10.1371/journal.pone.0183972)

Wei J, Shi Y, Hou Y, Ren Y, Du C, Zhang L, Li Y \& Duan H 2013 Knockdown of thioredoxin-interacting protein ameliorates high glucose-induced epithelial to mesenchymal transition in renal tubular epithelial cells. Cell Signaling 25 2788-2796. (https://doi. org/10.1016/j.cellsig.2013.09.009)

Yamagishi S, Inagaki Y, Okamoto T, Amano S, Koga K \& Takeuchi M 2003 Advanced glycation end products inhibit de novo protein synthesis and induce TGF-beta overexpression in proximal tubular cells. Kidney International 63 464-473. (https://doi. org/10.1046/j.1523-1755.2003.00752.x)

Zeisberg M \& Neilson EG 2010 Mechanisms of tubulointerstitial fibrosis. Journal of the American Society of Nephrology 21 1819-1834. (https:// doi.org/10.1681/ASN.2010080793)

Zhang X, Liang D, Chi ZH, Chu Q, Zhao C, Ma RZ, Zhao Y \& Li H 2015 Effect of zinc on high glucose-induced epithelial-to-mesenchymal transition in renal tubular epithelial cells. International Journal of Molecular Medicine 35 1747-1754. (https://doi.org/10.3892/ ijmm.2015.2170)

Zhou R, Yazdi AS, Menu P \& Tschopp J 2011 A role for mitochondria in NLRP3 inflammasome activation. Nature 469 221-225. (https://doi. org/10.1038/nature09663)

Zhuang Y, Ding G, Zhao M, Bai M, Yang L, Ni J, Wang R, Jia Z, Huang S \& Zhang A 2014 NLRP3 inflammasome mediates albumin-induced renal tubular injury through impaired mitochondrial function. Journal of Biological Chemistry 289 25101-25111. (https://doi. org/10.1074/jbc.M114.578260)

Received in final form 24 May 2018

Accepted 18 June 2018 (c) 2018 Society for Endocrinology Published by Bioscientifica Ltd. Printed in Great Britain 